\title{
BK virus-associated nephropathy in a lung transplant patient: case report and literature review
}

\author{
Thomas Crowhurst ${ }^{1,2^{*}}$ (D) James Nolan ${ }^{3}$, Randall Faull ${ }^{1,4}$, Mark Holmes ${ }^{1,2}$ and Chien-Li Holmes-Liew ${ }^{1,2}$
}

\begin{abstract}
Background: BK virus-associated nephropathy (BKVAN) is a relatively common cause of renal dysfunction in the first six months after renal transplantation. It arises from reactivation of the latent and usually harmless BK virus (BK virus) due to immunosuppression and other factors including some that are unique to renal transplantation such as allograft injury. BKVAN is much rarer in non-renal solid organ transplantation, where data regarding diagnosis and management are extremely limited.

Case presentation: We report a case of a 58-year-old man found to have worsening renal dysfunction nine months after bilateral sequential lung transplantation for chronic obstructive pulmonary disease (COPD). He had required methylprednisolone for acute allograft rejection but achieved good graft function. Urine microscopy and culture and renal ultrasound were normal. BK virus PCR was positive at high levels in urine and blood. Renal biopsy subsequently confirmed BKVAN. The patient progressed to end-stage renal failure requiring haemodialysis despite reduction in immunosuppression, including switching mycophenolate for everolimus, and the administration of intravenous immunoglobulin (IVIG).

Conclusions: This very rare case highlights the challenges presented by BK virus in the non-renal solid organ transplant population. Diagnosis can be difficult, especially given the heterogeneity with which BKV disease has been reported to present in such patients, and the optimal approach to management is unknown. Balancing reduction in immunosuppression against prevention of allograft rejection is delicate. Improved therapeutic options are clearly required.
\end{abstract}

Keywords: BK virus, Nephropathy, End-stage renal failure, Lung transplantation, Case report

\section{Background}

BK virus (BKV) is a non-enveloped double-stranded DNA polyomavirus. It resides in renal tubular and uroepithelial cells, causing no sequelae in immunocompetent individuals [1]. Primary infection occurs in childhood and as many as $80 \%$ of adults demonstrate serological evidence of exposure [2]. Intermittent viral replication

\footnotetext{
* Correspondence: thomas.crowhurst@gmail.com

'Discipline of Medicine, University of Adelaide, Adelaide, SA 5000, Australia ${ }^{2}$ SA Lung Transplant Service, Royal Adelaide Hospital, Central Adelaide Local Health Network, 1 Port Road, Adelaide, SA 5000, Australia

Full list of author information is available at the end of the article
}

manifests as asymptomatic viruria in $7-15 \%$ of healthy people [3]. Immunocompromise can enable significant reactivation whereby $\mathrm{BKV}$ can progress from viruria to viraemia and cause end-organ disease, usually BKVassociated nephropathy (BKVAN) in renal transplant recipients and haemorrhagic cystitis in haematopoietic stem cell transplant recipients. Reports of BKVAN in other states of immunocompromise, especially after lung transplantation, are rare.

BKV viruria occurs in $25-30 \%$ of renal transplant recipients and $11-13 \%$ develop viraemia, with $1-10 \%$ progressing to BKVAN usually by 6 months post-transplant

(C) The Author(s). 2020 Open Access This article is licensed under a Creative Commons Attribution 4.0 International License, which permits use, sharing, adaptation, distribution and reproduction in any medium or format, as long as you give appropriate credit to the original author(s) and the source, provide a link to the Creative Commons licence, and indicate if changes were made. The images or other third party material in this article are included in the article's Creative Commons licence, unless indicated otherwise in a credit line to the material. If material is not included in the article's Creative Commons licence and your intended use is not permitted by statutory regulation or exceeds the permitted use, you will need to obtain permission directly from the copyright holder. To view a copy of this licence, visit http://creativecommons.org/licenses/by/4.0/. The Creative Commons Public Domain Dedication waiver (http://creativecommons.org/publicdomain/zero/1.0/) applies to the data made available in this article, unless otherwise stated in a credit line to the data. 
$[4,5]$. The key risk for BKVAN is degree of immunosuppression; other factors include $\mathrm{ABO}$ incompatibility, tacrolimus-containing regimen, donor-positive to recipientnegative serostatus, extremes of age and male sex [6-9]. Higher pre-transplant levels of neutralising anti-BKV antibodies may reduce the risk of BKVAN [10]. The rarity with which the disease affects native kidneys highlights unique characteristics of renal transplantation that engender a more permissible environment for reactivation; these include allograft injury from surgery and ischaemia, rejection, HLA mismatch impacting host immune activity in the allograft, and others [11, 12].

Screening for BKVAN is recommended after renal transplantation and involves monitoring for BKV viraemia via quantitative polymerase chain reaction (PCR), given viraemia is a reliable precursor to BKVAN [13]. Persistent or significant viraemia is pre-emptively managed with reduction of immunosuppression before allograft dysfunction arises [5]. Screening is not recommended in other solid organ transplantation. Electron microscopy for castlike urinary polyomavirus aggregates ('Haufen') is highly sensitive and specific for BKVAN, and may be particularly useful in paediatric patients where biopsy is difficult $[14,15]$. In renal transplantation, biopsy is reserved for when there is diagnostic uncertainty or when reduction of immunosuppression has not led to improvement in renal dysfunction or viraemia. Histological findings in BKVAN share similarities with other viral nephropathies and include intranuclear viral inclusions, tubular damage, and mononuclear or polymorphonuclear infiltrates in affected areas; confirmation occurs via positive immunohistochemistry (IHC) for simian virus 40 (SV40) large $\mathrm{T}$ antigen, which cross-reacts with BKV and other polyomaviruses like JC virus (JCV) [16]. The Banff Working Group Classification of Definitive Polyomavirus Nephropathy was published in 2018 on the basis of a large retrospective analysis of proven polyomavirus nephropathy cases; it seeks to provide a consensus morphologic grading scheme that reflects important clinical parameters including presentation at diagnosis, renal function after index biopsy, and future graft failure [6].

Reduction in immunosuppression is the only proven strategy for management of BKVAN, however there is no universally agreed approach. There is some evidence mTOR inhibitors, compared with calcineurin inhibitors and mycophenolate, could enable superior control of BKVAN without increasing risk of rejection [17, 18]. Other therapies such as intravenous immunoglobulin (IVIG), leflunomide and cidofovir are unproven but occasionally employed. Quinolone antibiotics have been shown to provide no benefit while increasing antimicrobial resistance [19]. Future treatments may include brincidofovir and allogeneic polyomavirus-specific $\mathrm{T}$ cell therapy $[20,21]$.

\section{Case presentation}

A 58-year-old man was noted to have 3 months of progressive renal dysfunction at routine outpatient followup for his bilateral sequential lung transplant, which was performed 9 months earlier for severe chronic obstructive pulmonary disease (COPD). Methylprednisolone alone was used for induction. He was found to have acute rejection (A1B0) on surveillance bronchoscopy at 2 months post-transplant and was managed with pulse methylprednisolone with good results. His immunosuppressive regimen consisted of prednisolone, tacrolimus and mycophenolate. Before the onset of renal dysfunction, his prednisolone dose was $10 \mathrm{mg}$ daily and mycophenolate dose was $500 \mathrm{mg}$ twice daily. Median tacrolimus trough level from months three to six posttransplant was $11.2 \mu \mathrm{g} / \mathrm{L}$ (interquartile range [IQR]: 8.6$13.7 \mu \mathrm{g} / \mathrm{L})$. He had not experienced further rejection and his graft function was good with a forced expiratory volume in $1 \mathrm{~s}$ (FEV1) of 2.441 (82\% predicted and 91\% of post-transplant baseline).

Other post-transplant issues included (a) positive galactomannan on three-month surveillance bronchoscopy without invasion which was managed with itraconazole, (b) respiratory syncytial virus and rotavirus at 3 months post-transplant, (c) steroid-induced diabetes mellitus which settled with reduction in prednisolone, (d) hypertension controlled with angiotensin receptor blockade, (e) persistent small left effusion drained at 10 months post-transplant, (f) asymptomatic cytolomegalovirus (CMV) viraemia detected at 10 months posttransplant and treated with valganciclovir, (g) iron deficiency anaemia due to dysplastic colonic polyps which were removed, (h) cataracts and (i) benign squamous papilloma affecting the right main bronchus anastomosis which was detected at 15 months post-transplant due to declining allograft function and which improved with balloon dilatation. Histological assessment did not demonstrate a viral aetiology for the bronchial squamous papilloma, however specific testing for human papilloma virus was not performed.

Background medical problems prior to transplant included coeliac disease, central sleep apnoea managed with oxygen, osteoporosis and hypercholesterolaemia. Pharmacological therapy at the time of detection of renal dysfunction, in addition to his immunosuppression, included: azithromycin, pantoprazole, candesartan, atorvastatin, calcium citrate, vitamin $\mathrm{D}$, annual zoledronic acid, magnesium supplementation plus prophylactic itraconazole, trimethoprim/sulfamethoxazole and valganciclovir.

The patient had a pre-transplant glomerular filtration rate (GFR) of $85 \mathrm{ml} / \mathrm{min} / 1.73 \mathrm{~m}^{2}$ and a stable baseline of $70 \mathrm{ml} / \mathrm{min} / 1.73 \mathrm{~m}^{2}$ at 6 months post-transplant; this relatively mild stepwise decline in renal function was attributed to multifactorial peri-operative renal injury, as is 
seen very often after lung transplantation. His renal function then progressively deteriorated over 3 months to reach a GFR of $35 \mathrm{ml} / \mathrm{min} / 1.73 \mathrm{~m}^{2}$ at 9 months posttransplant despite reduced tacrolimus trough levels over this period (median: $5.2 \mu \mathrm{g} / \mathrm{L}$ | IQR: $4.5-5.9 \mu \mathrm{g} / \mathrm{L}$ ). Urinary microscopy and culture analyses were bland on two separate occasions over 3 days with no haematuria, pyuria, decoy cells or casts. Ultrasound of the renal tract performed at the same time was normal with no evidence of obstruction and normal renal size. Given the absence of another identifiable cause and the immunosuppression, PCR for BKV was performed on samples collected at the same time as those for urinary microscopy and culture; the PCR was positive at $>10$ million copies $/ \mathrm{ml}$ in urine and 358,000 copies $/ \mathrm{ml}$ in blood. Nephrology input was sought. Mycophenolate was ceased, target tacrolimus level was reduced to $5 \mu \mathrm{g} / \mathrm{L}$, everolimus was commenced with a target level of 2.5 to $3 \mu \mathrm{g} / \mathrm{L}$ and a biopsy was planned.

A renal biopsy was performed 3 weeks after the positive BKV PCR result (Figs. 1, 2, 3 and 4). The biopsy comprised a formalin fixed $9 \mathrm{~mm}$ core of renal tissue including 50\% each of cortex and medulla. Routine renal biopsy haematoxylin and eosin histology sections were produced and routine histochemical stains performed. There were up to 7 viable glomeruli per section and no obsolescent forms. The glomeruli showed no morphologic abnormality. There was mild cortical fibrosis, less than $10 \%$ of cortical area, with Banff cil assigned. There was no cortical inflammation. The biopsy included a portion of an arterial vessel with mild to moderate arteriosclerosis. Arterioles were normal. In medullary tubules adjacent to the cortico-medullary junction were cells with abnormal nuclei consistent with viral cytopathic effect; nuclear inclusions were seen along with lymphocytic tubulitis and sloughed epithelial cells. In

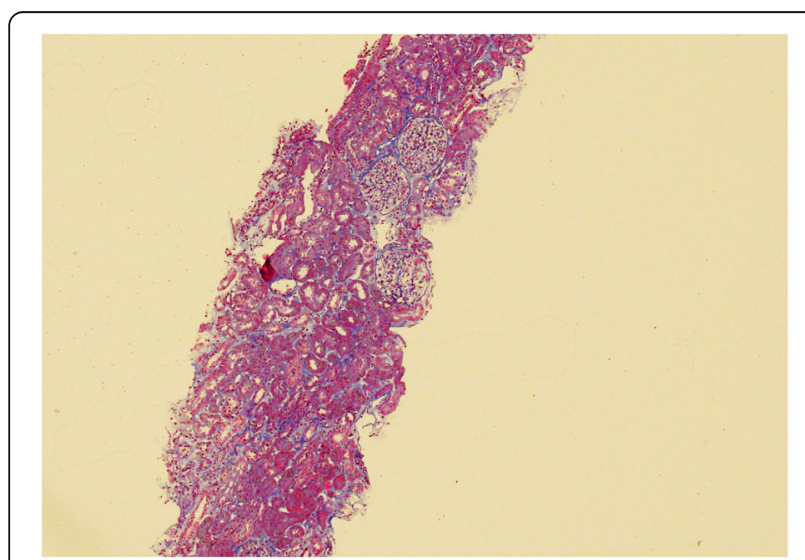

Fig. 1 Histological section of renal biopsy at 100 times magnification with trichrome stain showing no significant chronic damage to the renal cortical parenchyma.

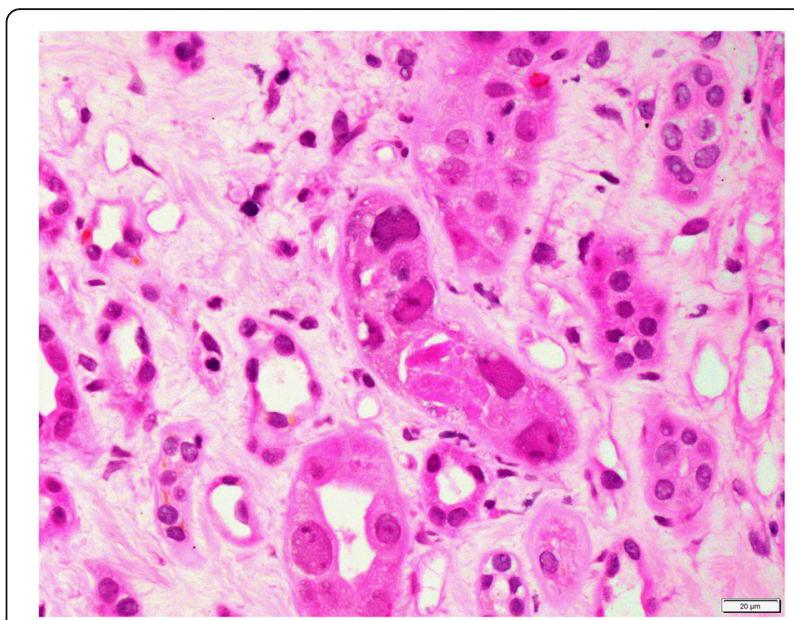

Fig. 2 Histological section of renal biopsy at 600 times magnification showing viral cytopathic effect

this region, IHC with antibody to SV40 was positive in the nuclei of epithelial cells. The involved tubules were quantified according to the method described by Nickeleit et al. [6]. This rendered a count of $2.5 \%$ and a $p v l$ score of 2 (1 to 10\%). The combination of Banff cil and $p v l 2$ produced an overall classification of polyomavirus nephropathy class 2 . Tissue was not submitted by the clinician for immunofluorescence. Electron microscopy of tissue received in glutaraldehyde showed glomeruli with ischaemic alterations only; no viral particles were seen in the tissue.

The combination of the clinical, virological and histological findings allowed a definitive diagnosis of polyomavirus nephropathy due to BKV. Decline in renal function continued despite reduction in immunosuppression. The quantitative BKV PCR in blood climbed over the ensuing 8 months to reach and remain $>10,000$,

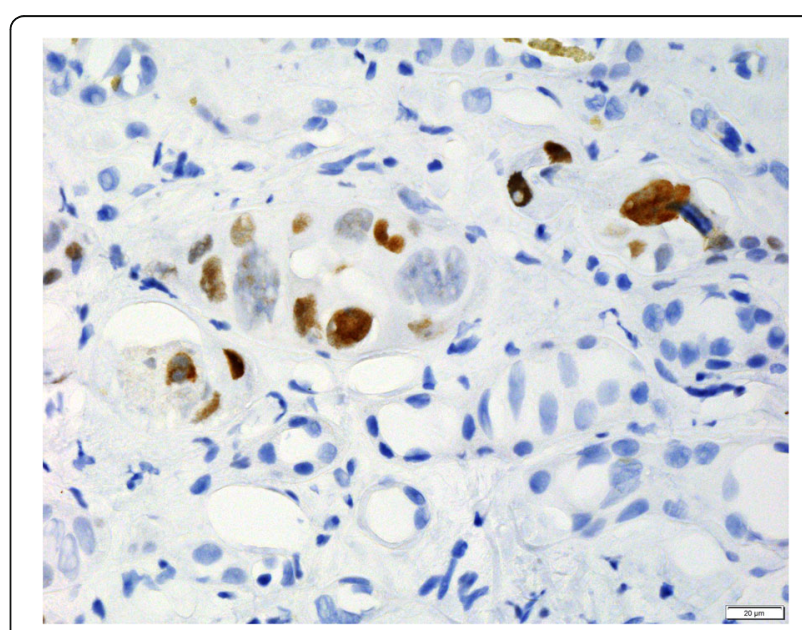

Fig. 3 Immunohistochemical stain with antibody to SV40 at 600 times magnification showing positively staining nuclei of tubular epithelial cells 


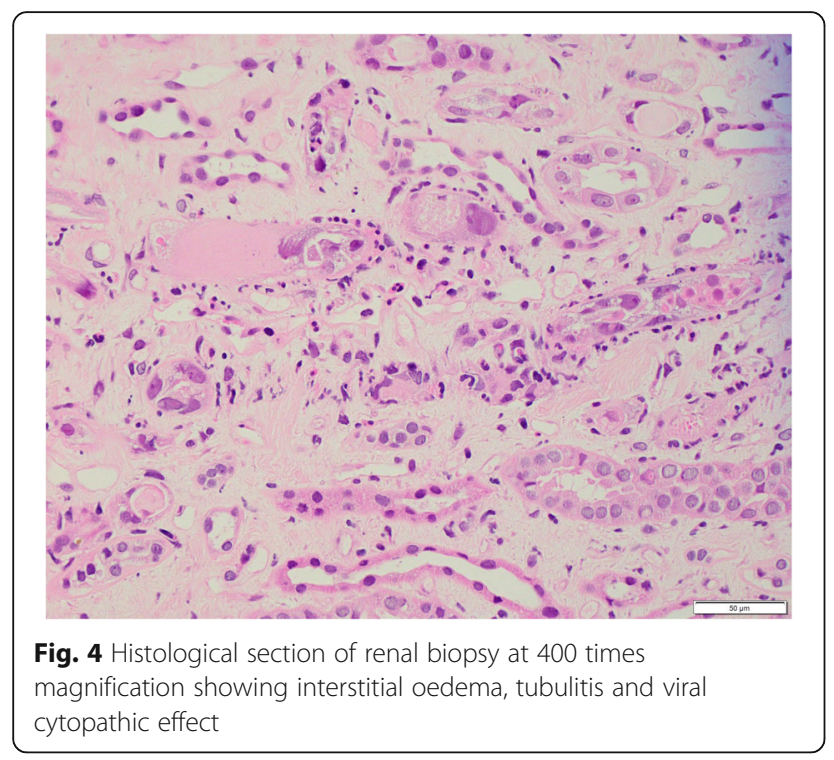

000 copies $/ \mathrm{ml}$. Three doses of IVIG were given over 2 months but this was then ceased due to an absence of effect. Patient progress is summarised in Fig. 5. He was regularly reviewed by nephrology and, at 20 months postdiagnosis of BKVAN and 29 months post-transplant, he had an arteriovenous fistula formed for planned commencement of haemodialysis.

\section{Discussion and conclusions}

This case is the eighth reported instance of BKVAN after lung transplantation, the seventh where a confirmatory biopsy has been performed and the first in which the Banff classification for polyomavirus nephropathy has been applied [22-28]. Reported cases are summarised in Table 1. Our case is worthy of discussion because of its rarity and because it highlights the dilemmas associated with organ-threatening infections in immunosuppressed transplant recipients.

Our case shares some similarities with those previously reported. Unlike renal transplant where BKVAN usually arises within 6 months, our case replicates the pattern of somewhat later presentation observed in earlier reports of BKVAN after lung transplant; median time to presentation across the eight reported cases is 19.5 months with IQR of 11-24 months. As with three of the other seven cases, our patient was more immunosuppressed than would be usual following lung transplantation due to the additional methylprednisolone for his acute rejection; in two of the three other cases the reason was also treatment for acute rejection whereas in the third it was neutropenia due to trimethoprim/sulfamethoxazole [22-24]. Higher levels of immunosuppression may have led to BKVAN in these patients, but this leaves the question as to what caused disease in the other four cases where immunosuppression was at routine levels. Urinary microscopy was bland in our patient, as it was in two of the other three cases for which results have been reported; only Okumura et al. have demonstrated decoy cells associated with BKVAN in a lung transplant patient $[25,26,28]$.

Our case is only the second reported instance where BKVAN has progressed to end-stage renal failure despite reduction in immunosuppression. This occurred in parallel with persistent extremely high BKV PCR levels measured in blood. There are no obvious factors that explain the poor outcome of our patient compared with the previously reported cases, however analysis is challenging given the paucity of data. BKV appears to have heterogenous manifestations in lung transplant recipients, noting the development of aggressive urothelial

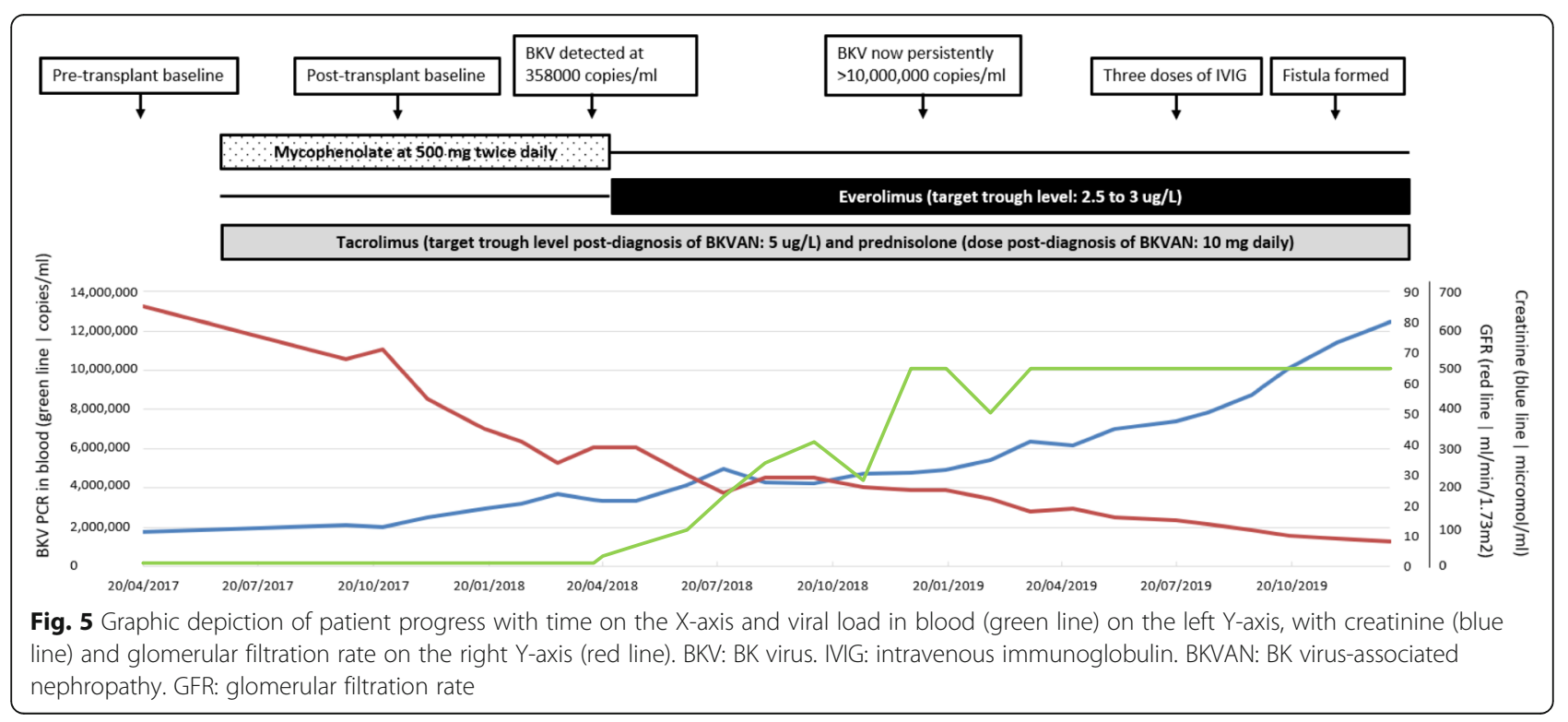




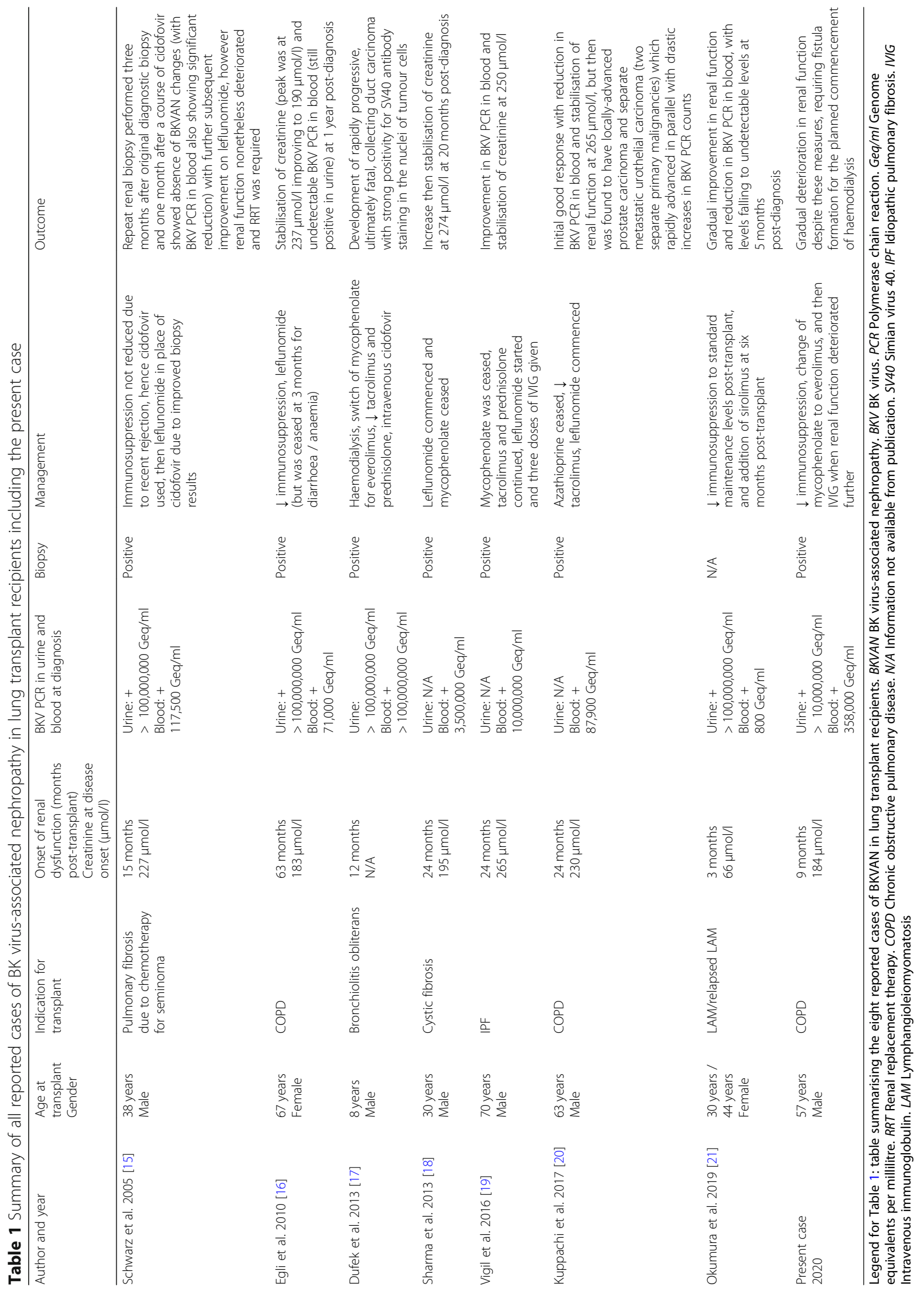


carcinoma in two of the reported cases almost certainly due to viral oncogenic effect, and with another report by Elidemir and colleagues describing haemorrhagic cystitis from BKV in a paediatric lung transplant recipient [24, 27, 29].

Some studies have attempted to determine whether non-renal solid organ transplant recipients should undergo to a similar screening regime to detect BK viraemia and prevent BKVAN. Barton and colleagues performed a prospective cross-sectional study of consecutive non-renal solid organ transplant recipients with unexplained chronic renal dysfunction of at least 3 months duration, with $65 \%$ of their 34 subjects being lung transplant recipients [30]. None of the patients had viraemia and only $15 \%$ had viruria; they associated viruria with mycophenolate use and a history of CMV disease, but GFR was similar in those with and without viruria. Thomas et al. undertook a prospective study of 50 lung transplant recipients, analysing urine and blood samples over a 17-month period for BKV but also JCV and SV40 [31]. All blood samples were negative. Urine was positive for BKV on at least one occasion in $32 \%$ of patients, while JCV and SV40 were detected at least once in 24 and $12 \%$ of subjects respectively. Doucette et al. performed a 9-month study of BKV in 60 patients with non-renal solid organ transplants, with $47 \%$ being lung transplant recipients; viruria was found in $15 \%$ but viraemia was not detected and there was no significant difference in GFR between those with and without viruria [32]. These studies seem to suggest that although polyomavirus viruria is common and harmless in lung transplant recipients, viraemia and BKVAN appear to be rare events.

The apparent clinical insignificance of BKV viruria has, however, been questioned by another more recent study by Thomas and colleagues [33]. They followed 99 lung transplant patients for 4.5 years with urine samples tested for BKV, JCV and SV40. Polyomavirus viruria occurred at least once in 66\% of cases (BKV 42\% | JCV 28\% | SV40 $7 \%$ ) and was positively associated with COPD but, surprisingly, negatively associated with acute rejection. Patients with viruria did not have significantly different renal function overall, however transient dysfunction was temporally associated with viruria episodes. Importantly, BKV viruria was associated with reduced survival however the magnitude of this effect was not reported; viruria was associated with chronic lung allograft dysfunction (CLAD) as a cause of death, with $26 \%$ of those with viruria dying of CLAD versus $10 \%$ of those without $(p=0.047)$. Causation is unproven and multiple other factors may explain these findings, but this study raises questions.

There are no data beyond case reports to indicate the reliability of BKV viraemia as a surrogate marker for risk of BKVAN in lung transplant recipients. The evidence in renal transplant recipients is strong [13]. Razonable and colleagues conducted a retrospective analysis of samples collected during a longitudinal study of CMV in solid organ transplant recipients including renal transplants but not including lung transplants [34]. BKV viraemia was found in $26 \%$ of renal, $6.7 \%$ of heart and $4.1 \%$ of liver transplants in the first year post-transplant, at a median of 100 days. All three positive cardiac transplant cases and one of five positive liver cases developed BKV viraemia after treatment for acute allograft rejection. None of the non-renal solid organ transplant patients with BKV viraemia developed renal dysfunction. Salama et al. found no BKV viraemia and no association between BKV viruria and renal function in 41 liver transplant recipients [35]. Louches et al. conducted a prospective longitudinal study of a consecutive sample of 28 heart transplant patients, finding $21 \%$ developed viraemia and $43 \%$ developed viruria; two of the five viraemic patients developed renal impairment [36]. Application of these data to lung transplant recipients is difficult. We believe that the optimal approach at this time is to monitor renal function in lung transplant recipients regularly and to test for BKV when there is persistent renal dysfunction of uncertain cause; however, we feel there is insufficient evidence to support routine surveillance for BKV viraemia in all lung transplant recipients. BKV viruria is relatively common in this patient population and does not appear to be sufficiently correlated with end-organ disease to warrant its use as a surveillance measure. Biopsy remains important for many reasons including rare cases of nephropathy from other polyomaviruses [37].

$\mathrm{BKV}$ is a rare but important cause of disease in lung transplant recipients with manifestations including BKVAN, haemorrhagic cystitis and urothelial carcinoma. Research could examine factors causing BKV reactivation and disease in these patients; it is interesting to consider whether donorpositive to recipient-negative serostatus might be a risk factor and, if so, whether this would imply BKV transmission via lung transplantation. The optimal approach to diagnosis is unclear and the role of screening requires further investigation. Improved treatments are required and may include allogeneic polyomavirus-specific $\mathrm{T}$ cell therapy.

\section{Abbreviations \\ $B K V$ : BK virus; BKVAN: BK virus-associated nephropathy; PCR: Polymerase chain reaction; IHC: Immunohistochemistry; SV40: Simian virus 40; JCV: JC virus; IVIG: Intravenous immunoglobulin; IQR: Interquartile range; COPD: Chronic obstructive pulmonary disease; FEV1: Forced expiratory volume in $1 \mathrm{~s}$; CMV: Cytolomegalovirus; GFR: Glomerular filtration rate}

\section{Acknowledgements \\ None.}

Authors' contributions

TC collected the data and drafted the manuscript. JN extensively reviewed the manuscript, provided histology slides for inclusion and provided expert 
pathologist input. RF extensively reviewed the manuscript and provided input from a nephrology perspective. MH and CLHL both extensively reviewed the manuscript and provided input from a lung transplantation perspective. All authors have read and approved the manuscript.

\section{Funding}

No external funding was obtained for the preparation of this case report.

\section{Availability of data and materials}

All relevant data for this case are shared in this manuscript. Further provision of data will not be contemplated due to the priority of patient confidentiality.

\section{Ethics approval and consent to participate}

Written patient consent has been obtained for the publication of this manuscript and associated images. Given that the preparation of this case report only required retrospective review of existing clinical data, ethics approval from an ethics committee was not required.

\section{Consent for publication}

Written patient consent has been obtained for the publication of this manuscript and associated images.

\section{Competing interests}

The authors declare that they have no completing interests.

\section{Author details}

'Discipline of Medicine, University of Adelaide, Adelaide, SA 5000, Australia. ${ }^{2}$ SA Lung Transplant Service, Royal Adelaide Hospital, Central Adelaide Local Health Network, 1 Port Road, Adelaide, SA 5000, Australia. ${ }^{3}$ SA Pathology, Royal Adelaide Hospital, Central Adelaide Local Health Network, 1 Port Road, Adelaide, SA 5000, Australia. ${ }^{4}$ Central Northern Adelaide Renal and Transplantation Service, Royal Adelaide Hospital, Central Adelaide Local Health Network, 1 Port Road, Adelaide, SA 5000, Australia.

Received: 1 April 2020 Accepted: 26 July 2020

Published online: 14 August 2020

\section{References}

1. Viswesh V, Yost SE, Kaplan B. The prevalence and implications of BK virus replication in non-renal solid organ transplant recipients: A systematic review. Transplant Rev (Orlando). 2015;29(3):175-180. doi: 1https:/doi.org/ 10.1016/j.trre.2015.1002.1004. Epub 2015 Feb 1024

2. Knowles WA, Pipkin P, Andrews N, et al. Population-based study of antibody to the human polyomaviruses BKV and JCV and the simian polyomavirus SV40. J Med Virol. 2003;71(1):115-123. doi: 1https://doi.org/10.1002/jmv. 10450.

3. Polo C, Perez JL, Mielnichuck A, Fedele CG, Niubo J, Tenorio A. Prevalence and patterns of polyomavirus urinary excretion in immunocompetent adults and children. Clin Microbiol Infect. 2004;10(7):640-644. doi: 610.1111/j.14690691.2004.00882.x

4. Manzano Sanchez D, Jimeno Garcia L, Manzano Sanchez D, et al. Renal function impairment in kidney transplantation: importance of early BK virus detection. Transplant Proc. 2019;51(2):350-352. doi: 3https://doi.org/10.1016/ j.transproceed.2018.1012.1016. Epub 2018 Dec 1030.

5. Brennan DC, Agha I, Bohl DL, et al. Incidence of BK with tacrolimus versus cyclosporine and impact of preemptive immunosuppression reduction. Am J Transplant. 2005;5(3):582-594. doi: 510.1111/j.1600-6143.2005.00742.x.

6. Nickeleit V, Singh HK, Randhawa $P$, et al. The banff working group classification of definitive polyomavirus nephropathy: morphologic definitions and clinical correlations. J Am Soc Nephrol. 2018;29(2):680-693. doi: 6https://doi.org/10.1681/ASN.2017050477. Epub 2017052017 Dec 2017050426.

7. Dharnidharka VR, Cherikh WS, Abbott KC. An OPTN analysis of national registry data on treatment of BK virus allograft nephropathy in the United States. Transplantation. 2009;87(7):1019-1026. doi: 10https://doi.org/10.1097/ TP.1010b1013e31819cc31383.

8. Hirsch HH, Vincenti F, Friman S, et al. Polyomavirus BK replication in de novo kidney transplant patients receiving tacrolimus or cyclosporine: a prospective, randomized, multicenter study. Am J Transplant. 2013;13(1): 136-145. doi: 110.1111/j.1600-6143.2012.04320.x. Epub 02012 Nov 04328.
9. Demey B, Tinez C, Francois C, et al. Risk factors for BK virus viremia and nephropathy after kidney transplantation: A systematic review. J Clin Virol. 2018;109:6-12. https://doi.org/10.1016/j.jcv.2018.1010.1002 Epub 2018 Oct 1012

10. Pastrana DV, Brennan DC, Cuburu N, et al. Neutralization serotyping of BK polyomavirus infection in kidney transplant recipients. PLoS Pathog. 2012; 8(4):e1002650. doi: 1002610.1001371/journal.ppat.1002650. Epub 1002012 Apr 1002612

11. Martin-Gandul C, Mueller NJ, Pascual M, Manuel O. The impact of infection on chronic allograft dysfunction and allograft survival after solid organ transplantation. Am J Transplant. 2015;15(12):3024-3040. doi: 30https://doi. org/10.1111/ajt.13486. Epub 12015 Oct 13416.

12. Barten MJ, Zuckermann A. BK virus: a cause for concern in thoracic transplantation? Ann Transplant. 2018;23:310-21. https://doi.org/10.12659/ AOT.908429.

13. Hirsch HH, Randhawa PS. BK polyomavirus in solid organ transplantationGuidelines from the American society of transplantation infectious diseases community of practice. Clin Transplant. 2019;33(9):e13528. doi: 135https:// doi.org/10.11111/ctr.13528. Epub 12019 Apr 13510.

14. Singh HK, Andreoni KA, Madden V, et al. Presence of urinary Haufen accurately predicts polyomavirus nephropathy. J Am Soc Nephrol. 2009; 20(2):416-427. doi: 4https://doi.org/10.1681/ASN.2008010117. Epub 2008012009 Jan 2008010121.

15. Singh HK, Reisner H, Derebail VK, Kozlowski T, Nickeleit V. Polyomavirus nephropathy: quantitative urinary polyomavirus-Haufen testing accurately predicts the degree of intrarenal viral disease. Transplantation. 2015;99(3): 609-615. doi: 6https://doi.org/10.1097/TP.0000000000000367.

16. Wiseman AC. Polyomavirus nephropathy: a current perspective and clinical considerations. Am J Kidney Dis. 2009;54(1):131-142. doi: 1https://doi.org/10. 1053/j.ajkd.2009.1001.1271. Epub 2009 Apr 1025.

17. Moscarelli L, Caroti L, Antognoli G, et al. Everolimus leads to a lower risk of BKV viremia than mycophenolic acid in de novo renal transplantation patients: a single-center experience. Clin Transplant. 2013;27(4):546-554. doi: 5https://doi.org/10.1111/ctr.12151. Epub 12013 Jun 12113.

18. Wojciechowski D, Chandran S, Webber A, Hirose R, Vincenti F. Mycophenolate mofetil withdrawal with conversion to everolimus to treat BK virus infection in kidney transplant recipients. Transplant Proc. 2017;49(8): 1773-1778. doi: 17https://doi.org/10.1016/j.transproceed.2017.1706.1030.

19. Knoll GA, Humar A, Fergusson D, et al. Levofloxacin for BK virus prophylaxis following kidney transplantation: a randomized clinical trial. JAMA. 2014; 312(20):2106-2114. doi: 21https://doi.org/10.1001/jama.2014.14721.

20. Papanicolaou GA, Lee YJ, Young JW, et al. Brincidofovir for polyomavirusassociated nephropathy after allogeneic hematopoietic stem cell transplantation. Am J Kidney Dis. 2015;65(5):780-784. doi: 7https://doi.org/ 10.1053/j.ajkd.2014.1011.1020. Epub 2015 Jan 1017.

21. Tzannou I, Papadopoulou A, Naik S, et al. Off-the-shelf virus-specific T cells to treat BK Virus, Human herpesvirus 6, cytomegalovirus, epstein-barr virus, and adenovirus infections after allogeneic hematopoietic stem-cell transplantation. J Clin Oncol. 2017;35(31):3547-3557. doi: 35https://doi.org/ 10.1200/JCO.2017.3573.0655. Epub 2017 Aug 3547.

22. Schwarz A, Mengel M, Haller $\mathrm{H}$, Niedermeyer J. Polyoma virus nephropathy in native kidneys after lung transplantation. Am J Transplant. 2005;5(10): 2582-2585. doi: 2510.1111/j.1600-6143.2005.01043.x.

23. Egli A, Helmersen DS, Taub K, Hirsch HH, Johnson A. Renal failure five years after lung transplantation due to polyomavirus BK-associated nephropathy. Am J Transplant. 2010;10(10):2324-2330. doi: 2310.1111/j.1600-6143.2010. 03265.x. Epub 02010 Sep 03214.

24. Dufek S, Haitel A, Muller-Sacherer T, Aufricht C. Duct Bellini carcinoma in association with BK virus nephropathy after lung transplantation. J Heart Lung Transplant. 2013;32(3):378-379. doi: 3https://doi.org/10.1016/j.healun. 2012.1011.1033. Epub 2013 Jan 1012.

25. Sharma SG, Nickeleit V, Herlitz LC, et al. BK polyoma virus nephropathy in the native kidney. Nephrol Dial Transplant. 2013;28(3):620-631. doi: 6https:// doi.org/10.1093/ndt/gfs1537. Epub 2012 Dec 1018.

26. Vigil D, Konstantinov NK, Barry M, et al. BK nephropathy in the native kidneys of patients with organ transplants: clinical spectrum of BK infection. World J Transplant. 2016;6(3):472-504. doi: 4https://doi.org/10.5500/wjt. v5506.15503.5472.

27. Kuppachi S, Holanda D, Eberlein M, et al. An unexpected surge in plasma BKPyV viral load heralds the development of BKPyV-Associated metastatic bladder cancer in a lung transplant recipient with BKPyV nephropathy. Am J 
Transplant. 2017;17(3):813-818. doi: 8https://doi.org/10.1111/ajt.14057. Epub 12016 Oct 14021.

28. Okumura J, Nakahara Y, Nakaguro M, et al. BK virus-associated viruria and viremia in a patient with lymphangioleiomyomatosis after lung retransplantation: A case report and review of the literature on BK virus infection post-lung transplantation. J Infect Chemother. 2019;25(10):820824. doi: 8https://doi.org/10.1016/j.jiac.2019.1004.1002. Epub 2019 Apr 1023.

29. Elidemir O, Chang IF, Schecter MG, Mallory GB. BK virus-associated hemorrhagic cystitis in a pediatric lung transplant recipient. Pediatr Transplant. 2007;11(7):807-810. doi: 810.1111/j.1399-3046.2007.00778.x.

30. Barton TD, Blumberg EA, Doyle A, et al. A prospective cross-sectional study of BK virus infection in non-renal solid organ transplant recipients with chronic renal dysfunction. Transpl Infect Dis. 2006;8(2):102-107. doi: 110 1111/j.1399-3062.2006.00155.x.

31. Thomas $L D$, Vilchez RA, White $Z S$, et al. A prospective longitudinal study of polyomavirus shedding in lung-transplant recipients. J Infect Dis. 2007; 195(3):442-449. doi: 4https://doi.org/10.1086/510625. Epub 512006 Dec 510622

32. Doucette $\mathrm{KE}$, Pang $\mathrm{XL}$, Jackson $\mathrm{K}$, et al. Prospective monitoring of $\mathrm{BK}$ polyomavirus infection early posttransplantation in nonrenal solid organ transplant recipients. Transplantation. 2008;85(12):1733-1736. doi: 17https:// doi.org/10.1097/TP.1730b1013e3181722ead.

33. Thomas LD, Milstone AP, Vilchez RA, Zanwar P, Butel JS, Dummer JS Polyomavirus infection and its impact on renal function and long-term outcomes after lung transplantation. Transplantation. 2009;88(3):360-366. doi: 3https://doi.org/10.1097/TP.1090b1013e3181ae1095ff1099.

34. Razonable RR, Brown RA, Humar A, Covington E, Alecock E, Paya CV. A longitudinal molecular surveillance study of human polyomavirus viremia in heart, kidney, liver, and pancreas transplant patients. J Infect Dis. 2005; 192(8):1349-1354. doi: 13https://doi.org/10.1086/466532. Epub 462005 Sep 466514.

35. Salama M, Boudville N, Speers D, Jeffrey GP, Ferrari P. Decline in native kidney function in liver transplant recipients is not associated with BK virus infection. Liver Transpl. 2008;14(12):1787-1792. doi: 17https://doi.org/10. 1002/tt.21627.

36. Loeches B, Valerio M, Palomo J, Bouza E, Munoz P. BK virus in heart transplant recipients: a prospective study. J Heart Lung Transplant. 2011; 30(1):109-111. doi: 1https://doi.org/10.1016/j.healun.2010.1008.1028. Epub 2010 Oct 1016.

37. Milstone A, Vilchez RA, Geiger X, Fogo AB, Butel JS, Dummer S. Polyomavirus simian virus 40 infection associated with nephropathy in a lung-transplant recipient. Transplantation. 2004;77(7):1019-1024. doi: 10https://doi.org/10.1097/1001.tp.0000119156.0000152197.ca.

\section{Publisher's Note}

Springer Nature remains neutral with regard to jurisdictional claims in published maps and institutional affiliations.

Ready to submit your research? Choose BMC and benefit from:

- fast, convenient online submission

- thorough peer review by experienced researchers in your field

- rapid publication on acceptance

- support for research data, including large and complex data types

- gold Open Access which fosters wider collaboration and increased citations

- maximum visibility for your research: over $100 \mathrm{M}$ website views per year

At $\mathrm{BMC}$, research is always in progress.

Learn more biomedcentral.com/submissions 